\title{
PENGEMBANGAN KOMPETENSI MULTILITERASI DESAIN BERBASIS PADA PENERAPAN TRADISI KOMUNIKASI DI ERA INDONESIA 4.0
}

\author{
Agustina Kusuma Dewi ${ }^{1}$ \\ Desain Komunikasi Visual, Institut Teknologi Nasional Bandung \\ agustina@itenas.ac.id
}

\begin{abstract}
ABSTRAK
Digitalisasi informasi nyaris tanpa batas sebagai salah satu pengaruh yang masuk secara masif ke Indonesia dapat menjadi potensi yang positif sekaligus negatif terkait pemberdayaan pemuda sebagai aset bangsa. Multiliterasi adalah keterampilan menggunakan beragam cara untuk menyatakan dan memahami ide-ide dan informasi dengan menggunakan bentuk-bentuk teks konvensional maupun teks inovatif, simbol, dan multimedia. Berdasarkan premis tersebut, kajian ini mengidentifikasi bahwa konsep multiliterasi yang dirancang untuk menjawab kebutuhan keterampilan yang diperlukan di era digitalisasi informasi membutuhkan pengembangan kerangka berpikir pada tatanan konseptual maupun praktis, kaitannya dengan pemanfaatan teks yang bersifat multimodal. Riset ini menggunakan pendekatan penelitian campuran dengan desain pra-eksperimental one-shot case study dalam dua tahap. Tahap Pertama adalah pengembangan kuesioner satu fase untuk mengidentifikasi bentuk media dan bentuk informasi paling efektif sebagai sumber literasi, Tahap Kedua merupakan Analisis Dokumentasi yang menelaah beragam Tradisi Komunikasi dalam Proses Komunikasi Visual yang selama ini telah banyak diterapkan dalam Pendidikan Tinggi Desain. Hasil penelitian Tahap Pertama yang menggunakan 40 orang responden menunjukkan bahwa bentuk media dan bentuk informasi literasi paling efektif merupakan gabungan dari beberapa modalitas pembelajaran. Mendukung hal ini, hasil Analisis Dokumentasi juga menunjukkan bahwa Multiliterasi Desain di era Revolusi Industri 4.0 memerlukan pengembangan dan penguatan pada area Tradisi Komunikasi serta Konteks Komunikasi Media, agar dengan demikian dapat mendukung tercapainya ragam kompetensi multiliterasi desain secara beretika yang diperlukan untuk menghadapi Indonesia 4.0.
\end{abstract}

Kata kunci : Multiliterasi Desain, Indonesia 4.0, Kompetensi Multiliterasi

\begin{abstract}
The unlimited information digitalization as one of the influences that entered massively into Indonesia could be a positive and negative potential related to the empowerment of youth as a nation's asset. Multiliteration is the skill of using a variety of ways to express and understand ideas and information using conventional text forms as well as innovative text, symbols, and multimedia. Based on this premise, this study identified that the concept of multiliteration designed to answer the skills needed in the era of information digitalization requires the development of a framework of thinking in both conceptual and practical terms, in relation to the use of multimodal texts. This research uses a mixed research approach with a two-stage one-shot case study pre-experimental design. The first stage is the development of a one-phase questionnaire to identify the most effective forms of media and forms of information as sources of literacy, the second stage is documentation analysis that examines various communication traditions in the visual communication process that have been widely applied in design higher education. The results of the Phase One study that used 40 respondents showed that the most effective forms of media and information literacy forms were a combination of several learning modalities. Supporting this, the Documentation Analysis results also show that Multiliteration of Design in the Industrial Revolution 4.0 era requires development and strengthening in the area of Communication Traditions and Media Communication Context, so that it can support the achievement of a variety of ethical design competencies needed to deal with Indonesia 4.0.
\end{abstract}

.Keywords: Multiliteration Design, Indonesia 4.0, Multiliteration Competence
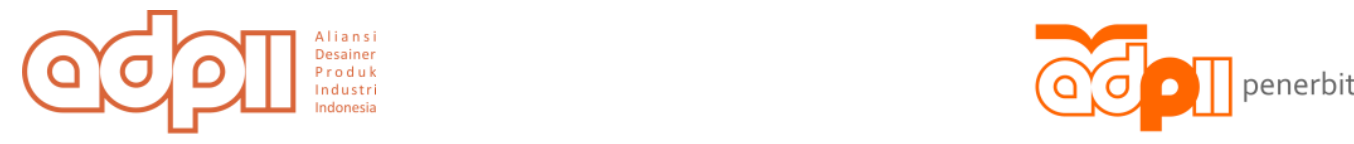


\section{PENDAHULUAN}

Permenristekdikti no 44 tahun 2015 pasal 11 menyebutkan bahwa karakteristik proses pembelajaran pada pendidikan tinggi diantaranya bersifat Holistik, yaitu proses pembelajaran mendorong terbentuknya pola pikir yang komprehensif dan luas dengan menginternalisasi keunggulan dan kearifan lokal maupun nasional; Integratif, yaitu capaian pembelajaran lulusan diraih melalui proses pembelajaran yang terintegrasi untuk memenuhi capaian pembelajaran lulusan secara keseluruhan dalam satu kesatuan program melalui pendekatan multidisiplin; Saintifik, yaitu capaian pembelajaran lulusan diraih melalui proses pembelajaran yang mengutamakan pendekatan ilmiah sehingga tercipta lingkungan akademik yang berdasarkan sistem nilai, norma, dan kaidah ilmu pengetahuan serta menjunjung tinggi nilai-nilai agama dan kebangsaan; dan Kontekstual, yaitu capaian pembelajaran lulusan diraih melalui proses pembelajaran yang disesuaikan dengan tuntutan kemampuan menyelesaikan masalah dalam ranah keahliannya.

Secara tidak langsung, tuntutan karakteristik proses pembelajaran tersebut memerlukan kemampuan literasi sebagai wujud dasar pengembangan budi pekerti yang bertujuan untuk mencapai tingkat melek aksara yang tinggi di Indonesia. Perkembangan teknologi mengakibatkan adanya pergeseran makna teks yang pada awalnya hanya diartikan sebagai kata-kata yang tercetak, namun sekarang menjadi bentuk multimodal. Kompetensi literasi mengalami peralihan menjadi multiliterasi, pengembangan dari literasi tradisional atau basic literasi [1]. Di era Rovolusi 4.0, kompetensi literasi menjadi sangat penting. Literasi mulai didefinisikan sebagai kemampuan untuk mengerti berbagai teks dalam berbagai bentuk yang lebih dari membaca dan menulis, termasuk ragam teks yang dimaksud berbentuk gambar, grafik, elektronik, termasuk kinestetik. Dengan kata lain, Pendidikan Tinggi Desain berperan sebagai agen perubahan dalam mengembangkan ragam literasi jamak atau multiliterasi desain pada pembelajarannya.

Wibur Schamm mengungkapkan bahwa secara garis besar dalam proses komunikasi, pesan adalah pernyataan yang didukung oleh lambang, merupakan paduan pikiran dan perasaan (ide, informasi, himbauan, perintah, larangan, keluhan, dsb), dimana lambang dapat berupa verbal/bahasa (lisan mau pun tulisan), atau pun non-verbal (visual, isyarat, gerak tubuh, mimik) [1]. Dalam hal ini, ide atau gagasan yang disampaikan bisa dikomunikasikan dalam bentuk gambar atau simbol atau lambang dan tanda yang bermakna. Karena adanya unsur seni yang didominasi oleh perasaan sekaligus unsur komunikasi yang dilandasi kesadaran, maka gambar, simbol, lambang atau tanda yang bermakna ini memerlukan jembatan untuk dapat dimaknai dengan terarah sesuai dengan tujuan yang ingin dicapai. Salah satu jembatan yang digunakan adalah komunikasi dan berbagai konsep yang menyertainya (mulai dari konsep komunikasi sebagai proses siklis untuk menyamakan makna sampai pada konsep media dan karakteristiknya) yang memberikan wacana sebagai landasan yang menyertai studi akademik lain dalam kajian ilmu desain.

Terkait hal ini, Revolusi Industri 4.0 memungkinkan makna diperdagangkan dan atau diinformasikan dalam bentuk visual, dengan potensi sifat persuasif sekaligus informatif-bahkan disruptif-terjadi secara bersamaan pada proses didalamnya. Ketidakjelasan ragam tanda yang dimunculkan dari multiliterasi adalah disebabkan karena teknologi memudahkan siapa pun meng-encode tanda-tanda dalam teks yang berpotensi memunculkan kode-kode ganda, kode-kode transestetik. Ketika informasi menjadi rumit dengan banyak konsep dan kata-kata struktural, visualisasi bisa membantu menguraikan kerumitan dan menguraikan kekusutan makna yang mungkin terjadi. Sebaliknya, informasi yang dituangkan dalam bentuk desain gambar saja kadang tidak cukup untuk menyamakan kerangka berpikir antara komunikator dengan komunikan atau klien si desainer sebagai produsen produk/jasa dengan konsumen.

Pada irisan inilah kemudian term (ilmu) komunikasi dapat berperan mendukung peran Pendidikan Tinggi Desain pada pengembangan kerangka berpikir secara konseptual, agar memenuhi karakter yang holistik, integratif, multidisiplin, saintifik dan kontekstual. Untuk mencapai tahap 'literat', kompetensi multiliterasi desain perlu diperkuat dengan adanya beberapa konsep tradisi komunikasi sehingga dapat
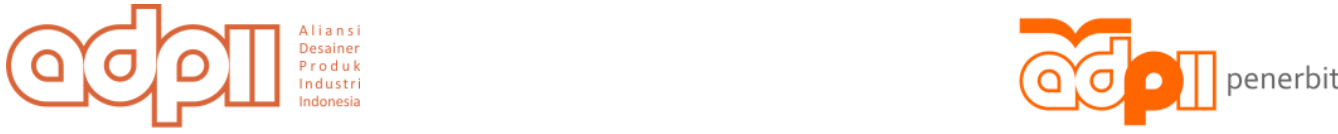
mendukung proses pendidikan desain menjadi lebih kuat dan sarat nuansa ilmu tanpa harus kehilangan akarnya sebagai seni dan budaya yang secara beretika memiliki struktur dan rasionalitas yang sanggup dipertanggungjawabkan di era digitalisasi informasi.

\section{Metoda Penelitian}

Merujuk pada Emzir (2009) yang mengklasifikasikan desain penelitian eksperimental ke dalam dua kelompok, maka penelitian ini merupakan desain variabel tunggal yang terkategori dalam penelitian praeksperimental dengan one-shot case study. Sebagai salah satu bagian dalam penelitian eksperimen, penelitian pra-eksperimental dilakukan untuk menggambarkan bentuk kasar dari suatu eksperimen, dengan maksud untuk menunjukkan kekuatan pengukuran dan nilai ilmiah suatu desain penelitian. Penelitian pra-eksperimental adalah kegiatan penelitian yang didalamnya belum melakukan randomisasi sampel dan tidak adanya kontrol yang memadai terhadap variabel-variabel pengganggu. Jadi hasil eksperimen yang merupakan variabel dependen itu bukan semata-mata dipengaruhi oleh variabel independen [2].

Dalam penelitian ini, ada dua data yang dikumpulkan yaitu data primer yang merupakan data terkait Multiliterasi Desain yang langsung didapat melalui kuesioner dan disebarkan kepada 40 responden, dan data sekunder adalah data tambahan bagi penelitian yang diperoleh dari studi literatur yang mendukung. Instrumen Penelitian yang digunakan adalah Kuesioner berbasis digital dan Analisis Dokumentasi. Data kuantitatif dalam penelitian ini menggunakan data nominal. Sampel adalah sebagian dari anggota populasi yang diteliti. Sampel pada penelitian ini terdiri dari satu kelompok, yaitu sampel yang akan menjadi subyek penelitian pra-eksperimental. Rancangan penentuan sampel dalam penelitian ini ditentukan berdasarkan Nonprobability/Nonrandom Sampling atau Sampel Tidak Acak, yaitu Convenience Sampling. Teknik sampling ini dipilih dengan pertimbangan bahwa desain penelitian yang dilakukan dalam penelitian ini adalah termasuk pada penelitian penjajagan.

Hasil penelitian mengidentifikasi bahwa sumber literasi paling efektif untuk mendukung multiliterasi desain adalah gabungan dari beberapa modal literasi, yang bisa berupa multimodal antara sumber oral, audio, visual, spasial, gestural dan/atau audio visual seperti yang ditunjukkan dalam Gambar 1.

40 responses
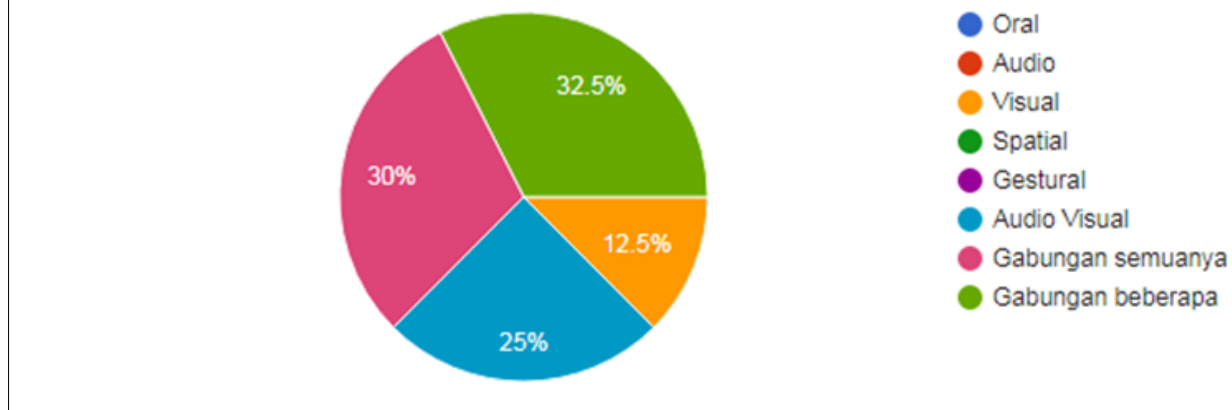

(20.

Gabungan beberapa

Gambar 1. Bentuk Media Paling Efektif sebagai Sumber Literasi (Analisis Pribadi, 2018)

Mendukung temuan yang diidentifikasi dalam Gambar 1, Gambar 2 menunjukkan bahwa sebesar 37,5 persen responden menyatakan multiliterasi desain dapat tercapai jika ada pemanfaatan unsur Fotografi, Ilustrasi, Tipografi, Simbol sebagai modal literasi dalam konteks pengembangan kemampuan berpikir menggunakan beragam sumber pengetahuan. Temuan ini menguatkan bahwa multi modal literasi dalam bentuk gambar (visual literacy), literasi dasar (basic literacy), literasi perpustakaan (library literacy), literasi media (media literacy) dan literasi teknologi (technology literacy) dapat mendukung Pendidikan Tinggi Desain menghasilkan potensi melek aksara yang sanggup mengintegrasikan beragam
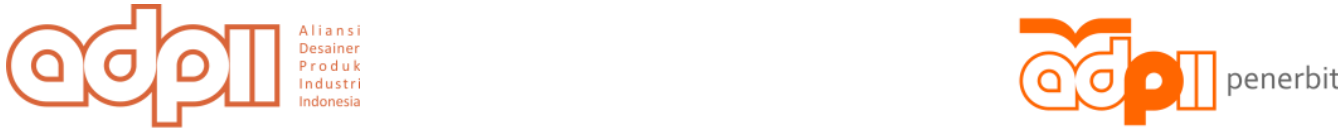
sumber informasi sebagai dasar pengemasan informasi yang kemudian disebarkan pada audiens baik dalam bentuk konseptual dan/atau prototipe produk.

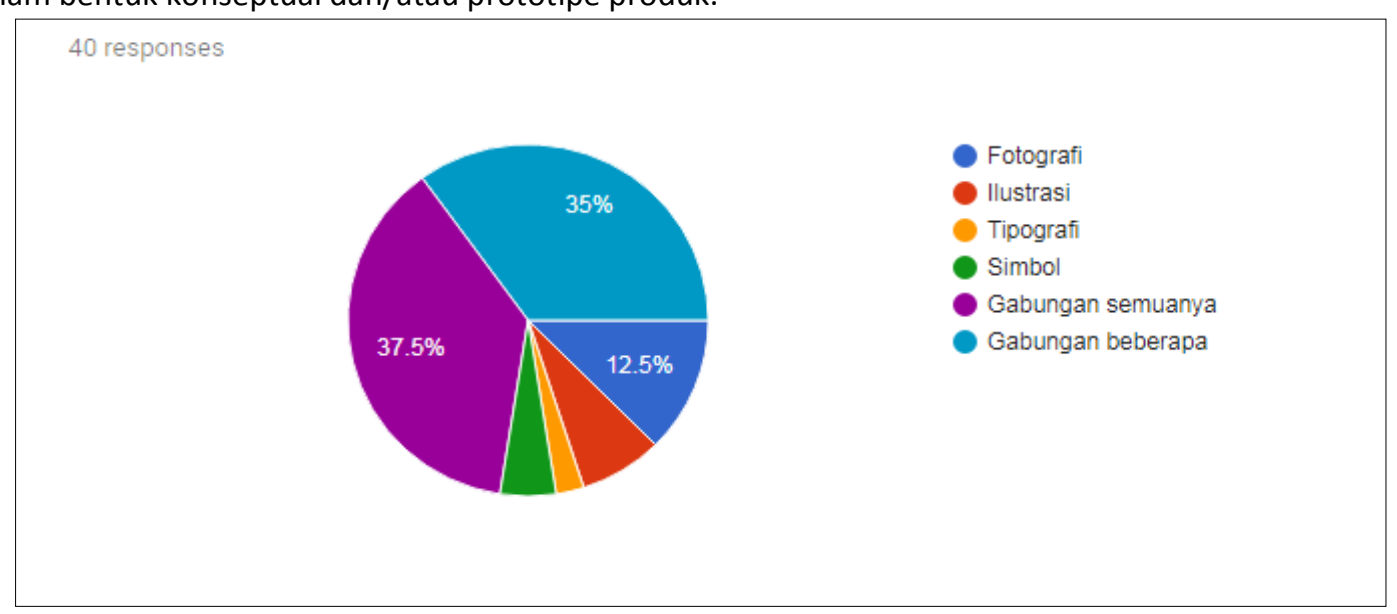

Gambar 2. Bentuk Informasi paling Efektif dalam Multiliterasi Desain (Analisis Pribadi, 2018)

\section{Diskusi}

Penguatan kompetensi Multiliterasi Desain dalam era Indonesia 4.0 dalam ranah komunikasi desain ditujukan untuk mencapai 10 kompetensi belajar secara khusus abad ke 21. Kesepuluh kompetensi tersebut menurut Binkley, dkk, dalam Abidin (2015) yakni : (1) kreativitas dan inovasi, (2) berpikir kritis, pemecahan masalah, dan pembuatan keputusan, (3) metakognisi, (4) komunikasi, (5) kolaborasi, (6) literasi informasi, (7) literasi teknologi informasi dan komunikasi, (8) sikap berkewarganegaraan, (9) berkehidupan dan berkarier, dan (10) responsibilitas personal dan sosial, termasuk kesadaran atas kompetensi dan budaya [1].

Hal ini dapat dicapai dengan adanya peningkatan kerangka berpikir yang integrative, multidiplin, holistik-saintifik dan konstekstual dari setidaknya 3 tradisi dalam komunikasi, yaitu :

1. Tradisi Semiotika, adalah ilmu tentang tanda dan cara tanda-tanda itu bekerja, dengan gagasan utamanya adalah konsep dasar dalam memaknai sebuah tanda yang didefinisikan sebagai sebuah stimulus untuk menunjukkan kondisi lain. Tiap simbol antara masyarakat satu dan masyarakat lain akan berbeda maknanya ketika digunakan dalam berkomunikasi. Dengan perhatian pada tanda dan simbol, semiotik menyatukan kumpulan teori-teori yang sangat luas dan berkaitan dengan bahasa, wacana dan tindakan-tindakan nonverbal [1].

Semiotik merupakan ilmu yang memiliki segi keunikan tersendiri. Budaya menjadi aspek yang esensial dalam kajian tradisi ini, sebab budaya menentukan tiap makna yang terkandung dalam sebuah simbol. Oleh sebab itu dalam semiotik tanda memiliki sifat arbitrer. Kebanyakan pemikiran semiotik melibatkan ide dasar triad of meaning yang menegaskan bahwa arti muncul dari hubungan di antara tiga hal: benda (atau yang dituju), manusia (penafsir), dan tanda [3]. Pola kajian dalam tradisi semiotik ini tidak hanya sekedar memaknai setiap bentuk tanda, tetapi juga memiliki aspek penting dalam melakukan persuasif terhadap orang lain. Pada titik inilah kajian semiotik memiliki segi keunikan tersendiri, yaitu bagaimana memaknai tanda dan mempersuasif orang lain dengan pemaknaan terhadap tanda tersebut.

Potensi multiliterasi desain dalam era Revolusi 4.0 dalam prosesnya yang dapat melahirkan Karya-karya desain dengan kode-kode dengan makna ganda, sehingga memerlukan penguatan analisis menggunakan Teori Semiotika yang salah satunya adalah Teori Roland Barthes, yang pada dasarnya hendak mempelajari bagaimana kemanusiaan (Humanity) memaknai hal-hal (Things). Memaknai (to signify) dalam hal ini tidak dapat dicampuradukkan dengan mengkomunikasikan (to communicate) [3]. Memaknai berarti bahwa objek-objek tidak hanya membawa informasi, tetapi juga mengkonstitusi sistem terstruktur dari tanda. Ini berarti, salah satu kompetensi multiliterasi desain yang harus dicapai dalam pendidikan tinggi desain adalah kemampuan pemahaman konseptual (conceptual understanding).
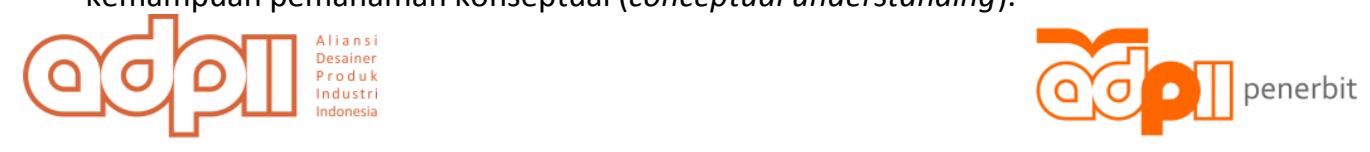
2. Tradisi Komunikasi Fenomonologi yang berkonsentrasi pada pengalaman pribadi termasuk bagian individu-individu yang ada saling memberikan pengalaman satu sama lainnya. Fenomenologi merupakan cara yang digunakan manusia untuk memahami dunia melalui pengalaman langsung [1]. Konsep pengalaman seseorang dalam memaknai sebuah fenomena menjadikannya sebagai sebuah pedoman untuk memahami konsep fenomena lain yang terjadi di hadapannya. Komunikasi dipandang sebagai proses berbagi pengalaman antar individu melalui dialog. Oleh karena itu, tradisi fenomenologis sangat bergantung pada persepsi dan interpretasi orang-orang tentang pengalaman subyektifnya. Dalam hal ini, multiliterasi desain diarahkan pada kompetensi critical thinking, berkaitan dengan kemampuan penalaran atas multi modal literasi, sehingga dari penalaran secara personal hingga kemudian sanggup mengkomunikasikan pengalaman tersebut melalui karya seni dan desain.

3. Tradisi Kritis yang dapat menjelaskan baik lingkup komunikasi antar personal maupun komunikasi bermedia [1]. Komunikasi dengan dasar multiliterasi desain dalam tradisi ini diharapkan dapat berperan sebagai alat transformasi masyarakat. Dalam hal ini, multiliterasi desain dengan tradisi kritis diharapkan dapat memunculkan kompetensi collaboration and communication serta creative thinking kaitannya dengan Desainer sebagai Agen Perubahan. Pendidikan Tinggi Desain di Era Indonesia 4.0 harus memiliki visi dan strategi untuk menghasilkan pembelajar dan calon desainer yang literat sekaligus sanggup untuk menyelaraskan kreativitas individu dan fungsi desain dalam merancang pesan sebagai rekomendasi solusi atas permasalahan yang terjadi pada ragam tatanan relasi sosial. Pada akhirnya, Pendidikan Tinggi Desain pun harus melek literasi digital, kaitannya dengan realitas bahwa Komunikasi Bermedia beririsan dengan konteks Intercultural Communication (Komunikasi Lintas Budaya), yang lebih jauhnya dapat dicapai dengan adanya kompetensi ragam literasi jamak. Kesanggupan Pendidikan Tinggi Desain untuk menghasilkan hal ini dapat membuka peluang baik bagi Pendidik maupun Mahasiswa untuk dapat memegang peranan penting dalam kemajuan bangsa dan perkembangan pengetahuan Desain sebagai sebuah ilmu.

\section{Kesimpulan}

Dari paparan di atas, disimpulkan bahwa sistem Pendidikan Tinggi Desain yang mengandung pendekatan literasi (literacy approach) haruslah mengandung dimensi pembelajaran multiliterasi yang dapat menggabungkan multi modal literasi baik sumber oral, audio, visual, spasial, gestural dan/atau audio visual dalam penerapannya pada saluran komunikasi visual diantaranya berupa Fotografi, Ilustrasi, Tipografi, Simbol dan/atau gabungan semuanya untuk mencapai kompetensi yang dibutuhkan pada Indonesia 4.0 yaitu Kompetensi Pemahaman Konsep (Conceptual Understanding) berhubungan dengan kemampuan seseorang untuk memiliki pemahaman tentang berbagai ilmu pengetahuan, Kompetensi Berpikir Kritis (Critical Thinking) merupakan kemampuan mendayagunakan kemampuan berpikir dan kemampuan menalar dan memberikan apresiasi, Kompetensi Elaborasi dan Komunikasi (Collaboration and Communication) merupakan kemampuan yang berhubungan dengan kesanggupan seseorang untuk bekerja sama dan berinteraksi dengan orang lain, serta Kompetensi Berpikir Kreatif (Creative Thinking) kompetensi yang berhubungan dengan kesangupan seseorang untuk menghasilkan gagasan atau produk dengan nilai lebih dan unik.

Meski demikian, dampak perkembangan teknologi yang terjadi di masyarakat tentu tidak selamanya dapat memberikan pengaruh yang 'semakin menguatkan karakter' dari karya-karya Seni dan Desain. Teknologi digital memungkinkan terjadinya produksi tanda dalam pesan komunikasi yang ketika didstribusikan pada ruang publik, tidak dikaji ulang makna serta etika konten yang terdapat didalamnya. Hal ini memberikan sebuah rekomendasi lanjutan bahwa meski Multiliterasi Desain di Era Indonesia 4.0 mengupayakan pencarian sebuah makna sekaligus alat ekspresi yang baru (means of expression) sekaligus juga melahirkan calon desainer yang kompeten menghadapi peralihan teknologi dan ragam tatanan interaksi ekonomi, sosial, budaya; namun Pendidikan Tinggi Desain dalam Making Indonesia 4.0 harus tetap berperan dalam menjaga komitmen pada etika profesi desain, baik sebagai akademisi dan/atau praktisi desain.
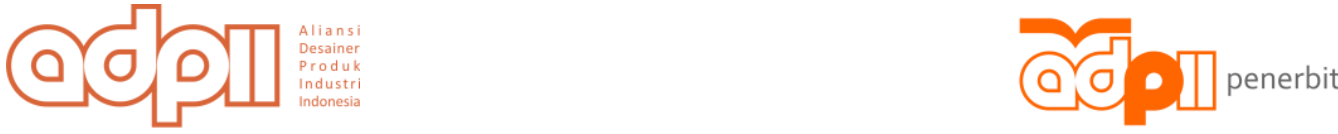


\section{Daftar Pustaka}

[1] Y. Z. Abidin, Manajemen Komunikasi: Filosofi, Konsep, dan Aplikasi, Bandung: Pustaka Setia., 2015.

[2] S. W. Littlejohn and K. A. Foss, Theories of Human Communication, Wadsworth Publishing Company, Page | 6 1996.

[3] Sugiyono, Memahami Penelitian Kualitatif, Bandung: Alfabeta, 2012.

[4] Kurniawan, Semiologi Roland Barthes, Magelang: Indonesiatera, 2001.

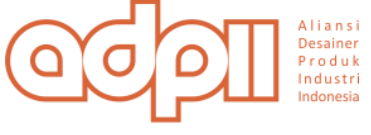

